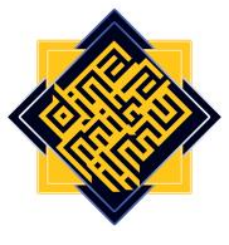

\title{
A Comparative Evaluation of the Lagos and IIUM Models of Islamic Teacher Preparation
}

\author{
Saheed Ahmad Rufai \\ Sokoto State University, Nigeria \\ e-mail:ahmadrufaisaheednew@yahoo.com
}

\section{Abstract}

The Muslim world has witnessed the emergence of several Islamic-based institutes and universities in the last four decades, in keeping with some of the recommendations of the World Conferences on Muslim Education. Yet there has not been a comprehensive study of the system as operated in various contemporary Muslim settings, with a view to assessing the degree of its adequacy and efficacy. The purpose of this paper is to carry out a comparative evaluation of the Bachelor's degree in Islamic Education programmes of the International Islamic University Malaysia (IIUM) and the University of Lagos in Nigeria. The choice of the two educational settings was informed by the impression that Malaysia offers some of the best practices in Islamic education, which may be used as standards in benchmarking for Islamic education in Nigeria, an African country with the largest Muslim population. The significance of such a study lies in its potentiality to expose the strengths and deficiencies of each of the models, as well as highlight their commonalities and differences with regard to educational aims, curricula, structures, teaching methods, and evaluation procedures. The paper is guided by three research questions seeking to elicit information or generate data about the nature of the two models being evaluated, the comparative strengths and weaknesses of the two models, and ameliorative propositions with potential to enrich or enhance the quality of the two models. The paper employs curriculum criticism and the analytic method in its comparative evaluation. The significance of the paper lies in its ameliorative propositions for curriculum enrichment purposes, aimed at making the two models better and of merit.

Keywords: comparative evaluation of curriculum models, Islamic education, Islamic education curriculum enrichment, model of Islamic education 


\section{A. Introduction}

The advent of Islam marked the genesis of higher learning among Muslims (Stanton, 1990). Right from early Islam, those who were knowledgeable $n$ the Qur'an were accorded leadership positions in discussion groups, where the Qur'an and its meanings were learnt. This line of argument is well captured in the literature of Islamic Education (Baiza, 2018; Amanullah, 2004; Niyozof \& Memon, 2020; Bustam-Ahmad \& Jory, 2018; Abaza, 2019; Munadi et al., 2019). As time progressed and with the formation of the Muslim religious setting into a theocratic state, learned men were appointed specifically to teach religious studies and to coordinate, administer or preside over the study circles known as halqas. The emergence of such circles within mosques marked the origins of formal institutions of higher learning in the Islamic tradition.

The content of higher learning was almost all-encompassing during the advent of Islam. Nakosteen (1964) posits that the virtually all-embracing nature of the curriculum is somewhat akin to the rich and extensive curriculum models for modern higher education. This statement is true in view of the fact that virtually all areas of learning are covered therein (Ibn Sina, 1984; Gillet, 1989; Arjmand, 2018; Ashraf \& Hussein, 1979; Langullung, 1988; Langullung \& Hashim, 2008; Rosnani, 1996; Rosnani, 2007; Mardamann, 2018), The specific subjects covered by the educational blueprint include Mathematics (Algebra, Trigonometry, and Geometry), Science (Chemistry, Physics, and Astronomy), Medicine (Anatomy, Surgery, Pharmacy, and Specialized medical branches), Philosophy (Logic, Ethics, and Metaphysics), Literature (Philology, Grammar, Poetry, and Prosody), Social Sciences, History, Geography, Political Disciplines, Theology (Comparative Religions, History of Religions, Study of Qur'an, Religious Tradition (Hadith), and other religious topics (Nakosteen, 1964). Nakosteen (1964: 53) offers a characterization of the curriculum implemented at a higher level in early Islam in a manner that captures well the essence of the curriculum in question where he argues that "the extent and depth of Muslim curriculum can be detected by references to a number of encyclopedia of general knowledge and specific disciplines, among scholars especially the Encyclopedia of the Ikhwan al-Safa (The Brethren of Purity or Sincerity), which was known to and respected by European schoolmen." This is strengthened by his further observation that a particular Arabic dictionary contained sixty volumes, with an illustration for each definition.

In view of the extensive nature of the curriculum of higher learning as described above, this paper seeks to examine the extent to which such rich Islamic higher learning tradition has been replicated in the context of today and therefore focuses on dominant Islamic education models. By dominant Islamic education models, in this context, are meant the Islamic higher education programmes that are being currently run in some of the leading Islamic universities such as Al-Azhar University in Egypt, Institut Agama Islam Negeri, or State Institute for Higher Islamic Education (IAIN) in Indonesia and the International Islamic University, Malaysia (IIUM). In fact, the comparative analysis focuses more on the IIUM owing to the fact that, being a relatively new Islamic university, it is expected to be a reflection of the most recent development in education among Muslims. It is not out of place to mention that Al-Azhar, which is situated in the Arab world, is the 
contemporary representation of the tradition of scholarship among Muslims, while IAIN is the modern characterization of Al-Azhar system outside the Arab world. In fact, IAIN, is a metamorphosis of the Sekolah Tinggi Islam which started with four Faculties i.e. Law, Religion, Economic, and Education, adopted and has maintained the curriculum of alAzhar from the onset (Zakaria, 2007). This is attributed to the fact that the pioneer staff and administrators of the Institute were graduates of Al-Azhar which is why the curriculum is a "carbon-copy of faculties in Al-Azhar" (Manaty, 2018).

It should be pointed out that the researcher's choice of the two models was not unconnected with the fact that he is a stakeholder in the two having studied and taught at the University of Lagos before proceeding to Malaysia where he earned his Ph.D at IIUM. This professional experience acquainted him well with the two models. After introducing the two models by discussing their aims, contents, structures, and methods, the comparative evaluation follows and is divided into three main sections. The first part outlines the programme objectives and learning experiences for evaluation. This is done through the assessment of the suitability of the objectives and experiences for an Islamic education programme. The second section evaluates the programme structure and modes of evaluation. This section focuses attention on the sequence, structure, arrangement, or organization of the programme alongside the procedures being employed for judgments and decisions. The third section is primarily concerned with a comparative critique of the programmes with a view to exposing the extent to which the programmes are capable of producing ideologically independent Islamic teachers who themselves are truly capable of implementing curricula in Muslim settings. The ultimate goal of this section is to expose the areas of both divergence and convergence between the Islamic models of education. In order to achieve a systematic engagement, this study is guided by three research questions namely, What is the nature of the Lagos and IIUM Model of Islamic Education?; What are the comparative strengths and deficiencies of the Lagos and IIUM Models of Islamic Education?; and What ameliorative propositions have potentials to enrich the two Models of Islamic Education?

\section{B. Literature Review}

It is noted that the curriculum of Muslim higher education was rich and virtually allencompassing. It is remarkable that Southeast Asia has earned itself an enviable reputation as the region with arguably the most impressive record of development in Islamic education, outside the Arab world (Sirajudeen, 2019; Hasan, 2018; Mansfield, 1989; Leopp, 2007; Fraser \& Paraha, 2002). This may not be unconnected with the fact that many governments in the region have demonstrated their favourable dispositions to Islamic education through massive funding and material support (Bustamam-Ahmad, 2018). This probably explains why a searchlight may always be beamed towards the region in an attempt to determine the degree of the faithfulness of dominant models of Islamic education to the Islamic learning tradition. This is a rationale for the choice of IIUM in this study. A further, critical engagement with the scholarship of Islamic higher education especially with regard to the curriculum is the subject of this section. 
In the Abbasid period, the curriculum in question included dogmatic theology, metaphysics, medicine, astronomy, philology, syntax, rhetoric, prosody reading, composition, logic, dialectic, chemistry, mathematics, history, agriculture, phrenology, magic, and astrology. These subjects cover what is characterized as both religious sciences and secular sciences (Jacobs, 1989; Jenson, 1998; Leopp, 2007; Muhammad, 2018; Mardman, 2018).

Nakosteen (1946:53), as well as Baloch \& Al-Fendi (1980), offer a different classification of the subjects where he identifies as components of the curriculum of Muslim higher education in early Islam, mundane studies, religious studies, and philosophical studies. In a similar token, Nakosteen (1964: 54) alludes to al-Katib's Mafatih al-Ulum (the Keys of the Sciences) which he regards as containing a similar scope but a different classification of knowledge which excludes the mundane studies and is rather of two main branches, namely the indigenous science and the exotic science. The curriculum components involved at that level are said to have later constituted the direction of higher Islamic education in the context of today, especially in Indonesia and Malaysia (Hasan, 2018; Shamsul \& Aziz, 2018; Bajunid, 2018).

It is unmistakable from the foregoing that the curriculum of Muslim higher education hardly eluded a body of knowledge that is not represented therein (Khairiah \& Sirajuddin, 2019; Manuty, 2018). However, it has been noted that the curriculum under discussion is remarkable in many ways. Firstly, it was not organized. Secondly, it gave utmost liberty to the scholars and the students. Thirdly, it grew in a most natural way out of the traditions of the Arabs and was molded into a system with the help of alien nations which accepted Islam by and by. Fourthly, its main aim and goal was a better understanding of Islam. It was in fact that last reason which dominated the whole system throughout the centuries (Zakaria, 2007; Zaman, 2018; Saeed, 2018). Yet, it is noteworthy that the content of higher learning in the Islamic tradition of the early days produced notable scholars who ranked high in the estimation critical assessors (Stanton, 1990; Tritton, 1957; Zakaria, 2007; Zakariyah, 2008; Zaman, 2018; Azra, 2018; Saeed, 2018; Shamsul \& Aziz, 2018; Abu Bakar, 2018). That was the situation in the face of the absence of an organized system and a lack of uniformity in the rules and regulations that guided the system. However, there was a remarkable uniformity in the pedagogy and classroom arrangement at all levels.

Makdisi (1981:80) puts the foregoing in a better perspective where he rationalizes that though there are differences in the sequence of courses that should be followed in the curriculum of Muslim higher education, "a pattern is noticeable." He adds that contrarily, "the sequences of courses found in the biographical notes of professors, either in reference to the courses they taught or to their own careers as students, indicate the lack of prescribed pattern." (p.80). Conversely, he posits that "the lack of a unified programme of studies should not be cause for surprise; as it was in part due to the fact that the founder of an institution of learning had freedom of choice in the organization of his foundation, including the choice of courses taught" (p.8o). The implementation of the curriculum of Muslim higher education was characterized by the system of halaqah which is a term used to mean a circle or ring in reference to the seating arrangement which was normally that of 
a circle. The teacher normally sat on a cushion or dais and learned against a wall or pillar in order to make his delivery.

\section{Research Methodology}

This paper employs a combination of methods comprising curriculum criticism and the analytic method. The relevance of curriculum criticism to the study lies in its application to studying educational materials and programmes. Its relevance to the study also lies in its primary focus on information collection and reporting techniques. It is consistent with such principles that this paper obtained information on each of the four models involved and reported such information from the perspective of a curricularist. The use of curriculum criticism for both educational materials and settings has received sufficient attention in the scholarship of the present subject and others. However, it is noteworthy that "the majority of the literature focusses on methods and examples of criticism of educational settings, perhaps because critics have assumed literary criticism can be adapted relatively easily to the criticism of published curriculum material..." (Klieberd, 1992; Ross, 1984: 47).

The relevance of the analytic method however lies in the hypothetical thinking that the four models being evaluated are inadequate and their inadequacies can only be clearly exposed through the instrumentality of such a method (Kosterec, 2016). The systematic procedure of engaging with the subject of this paper is, therefore, to critically examine the literature on the curriculum of higher Islamic education in the Islamic tradition before providing background analyses and content descriptions on the four selected contemporary models, one after the other, for comparative evaluation in the subsequent section. It is not out of place to subject to analysis at this juncture the two models selected for comparative evaluation in this study, with a view to establishing the extent to which they are faithful to the Islamic educational tradition as analysed above.

\section{The IIUM Model}

The International Islamic University of Malaysia (IIUM) is a relatively successful attempt to modify the Muslim education system in keeping with the recommendations of the World Conference on Muslim Education held at Makkah in 1977. Contribution to the establishment of International Islamic Universities in addition to setting up the Islamic Educational, Scientific and Cultural Organisation (ISESCO) and the World Center for Islamic Education, was a resolution made by the Organisation of Islamic Conference (OIC), Jeddah, in keeping with the recommendations of the Makkah Conference (Saqeb, 2000). Among the Islamic universities that the OIC helped to establish, IIUM "has emerged as a unique Islamic university" as it "set out for itself a clear vision and a mission statement for whose fulfillment the University and its various Faculties and Departments have been working since 1983 in all seriousness and with dedication" (Saqeb, 2000: 51).

In his concept paper entitled "Islamic University, Malaysia: Concept and Rationale" prepared in 1982, Hassan (1982) emphasized the need for Muslim societies to be less dependent on the knowledge provided by Western institutions. Muslim intellectuals and 


\section{Saheed Ahmad Rufai}

scholars perceived an Islamic university "as a key institution for the liberation of the Muslim mind from the lingering colonial influences and cultural enslavement to the neoimperialistic and hegemonic West" Hassan (2009: 11). Concerning the Islamic nature of the curriculum of such a university, it was established that the Islamic philosophy of knowledge and education should be the basis of the instruction of all the disciplines and that "Muslim as well as non-Muslim instructors should be required to know the Islamic philosophy of knowledge and Islamic world view well enough to integrate them in their instruction and research" (p.12).

\section{Objectives}

The objectives of the university, according to Hassan (2009: 14), "envisioned the reestablishment of the primacy of Islam in all fields of knowledge and the propagation of knowledge in the spirit of submission to God (tawhid)". Pursuant to the realization of those laudable objectives the Vision and Mission statements of IIUM were clearly articulated and are reproduced in what follows.

\section{Vision}

The International Islamic University Malaysia aims at becoming a leading international center of educational excellence which seeks to restore the dynamic and progressive role of the Muslim Ummah in all branches of knowledge.

\section{Mission:}

The acronym III CE or "Triple I.C.E." which stands for,

i. Integration of Revealed and Acquired Knowledge in Religious and Secular subjects;

ii. Islamization of all branches of sciences and life and culture of the University and of all its staff and students;

iii. Internationalization of knowledge, expertise, research, qualification, and standards of the University;

iv. Comprehensive nature of the University work; and

v. Excellence in every aspect of the University's performance.

The above vision and mission imply among others that the university is committed to the integration of the physical and spiritual elements in the propagation of knowledge as there is not supposed to be any compartmentalization in the dissemination of knowledge. IIUM has since been performing to the admiration of Muslims in its pursuit of the objectives. According to Saqeb (2000), the university "has won a worldwide repute and has been recognized as one of the best universities in the region" owing to its various academic programmes (its teacher education programme inclusive), teaching, research, and various cultural activities (p.51). In fact, the university "has occupied an important position in the world" (Amanullah, 2004:29) which is why its own programmes (the teacher education model inclusive) may be regarded as an improved version of other dominant Islamic-based programmes such as those of Al-Azhar and IAIN and other Islamic universities. 
The IIUM Faculty of Education (2021) characterizes the programme articulates the purpose of the Bachelor's programme in Islamic Education (2021), as:

i. Producing graduates in the field of Islamic Education to meet the needs of the Ministry of Education;

ii. Improving the quality of teacher professionalism for the secondary level specifically for teaching and learning in the field of Islamic Education in school;

iii. Producing professionals with the capacity to translate the theories of teaching and learning and demonstrate them in their pedagogical practices;

iv. Promoting the culture of continuous research in among secondary school teachers operating in related fields;

v. Preparing professional manpower capable of leading students aright through their learning and character

The salient components of the programme comprise the introduction of students to foundations of education and knowledge in the teaching profession. This is normally taken before students advance to two areas namely Education, its major theories and principles; and Islamic Education. Organization of the school, its curriculum, and the components or areas in Islamic Education are among the salient areas being covered at the early stage. In the second year, there is the strengthening of the content of Islamic Education, as the student becomes familiar with the teaching and learning process that takes place in the classroom. The third year presents the opportunity to experience hands-on in researching, planning, preparing, and teaching in a mock classroom, as well as learning to develop, conduct, interpret and report assessments of students' performance.

In Practicum I (School Orientation Program), students are placed in the school to experience the management, organization, and culture of the school, and classroom teaching. In the fourth year after completing the remaining courses, Students take in their last year on their programme a teaching practicum under the supervision of experienced teachers, school administrators, and university-based supervisors. Research knowledge and skills, necessary for postgraduate studies or for a career as a researcher, are among other skills that students are equipped with, in addition to other components of their training as teachers. The required courses are presented below in a tabular form.

Table 1.1 showing the curriculum structure of the IIUM Model (2021)

\begin{tabular}{|c|c|}
\hline \multicolumn{2}{|l|}{ :University Required Courses ( 20 credit hours) } \\
\hline \multicolumn{2}{|l|}{ MPU 3122: Tamadun Islam dan Tamadun Asia (TITAS) } \\
\hline \multicolumn{2}{|l|}{ OR } \\
\hline \begin{tabular}{|l|l|} 
UNGS 2060: Malay Virtues, Heritage \\
and Malaysian Society
\end{tabular} \mid $\begin{array}{l}\text { LM } 1030 \text { and LM } 1031 \\
\text { Bahasa Melayu I and II untuk } \\
\text { Antarabangsa OR }\end{array}$ & \begin{tabular}{l|l|} 
Pelajar & LM 1040 and LM 1041 \\
& Bahasa Melayu I and II untuk Pelajar \\
Antarabangsa (Nusantara)
\end{tabular} \\
\hline \multicolumn{2}{|l|}{ AND } \\
\hline \multirow{3}{*}{\begin{tabular}{|l|l|} 
UNGS 2011: Creative Thinking and & Usrah 1 (BUDI) Package \\
Problem Solving & Usrah 2 (BUDI) Package \\
Leadership Package 1 \\
Leadership Package 2 \\
Skills Package 1 \\
& Skills Package 2
\end{tabular}} & LE 4000: English Academic Writing \\
\hline & $\begin{array}{l}\text { TQ 1001: Tilawah Al Quran } 1 \\
\text { TQ 2001: Tilawah Al Quran II }\end{array}$ \\
\hline & $\begin{array}{l}\text { LQ 1008: Quranic Language I } \\
\text { LQ 2008: Quranic Language II }\end{array}$ \\
\hline
\end{tabular}

Dinamika Ilmu, Volume 21(2), 2021 


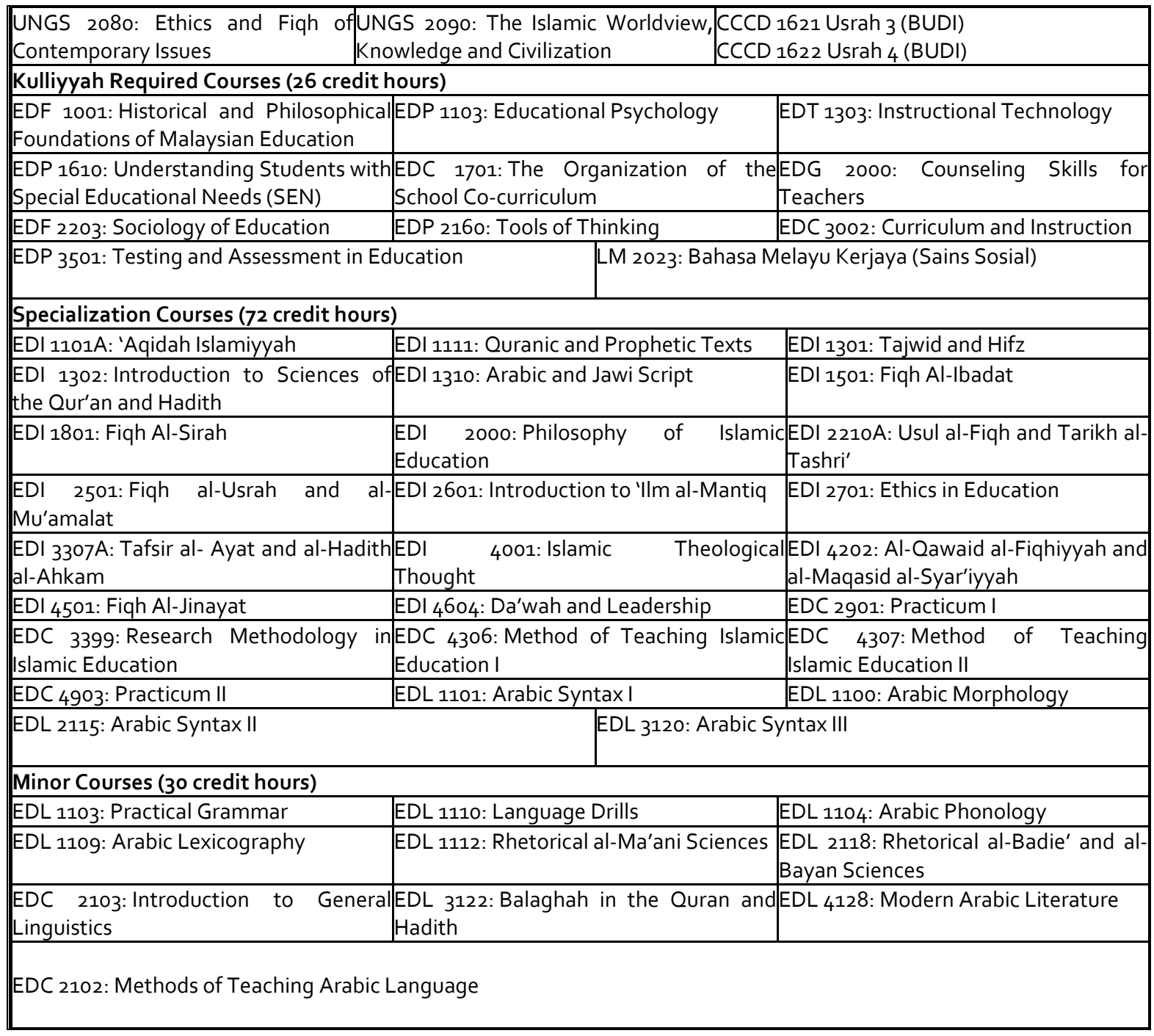

\section{E. The Lagos Model}

The Faculty of Education, the University of Lagos, which houses the Bachelor's degree programme in Islamic Education (B.A.Ed.) was founded in 1964, following the founding of the university itself in 1962 (Faculty Prospectus, $2010-2012$ ). In 1967, the Faculty was merged with the Federal Advanced Teachers' College (FATC) which had been established close to the location of the permanent site of the university. The merger culminated in the founding of a college of Education in keeping with "the general collegiate structure of the University at that time, with a provost as head of the College" (p.2), which handled the teaching of both professional education discipline and content teaching. Given that the Federal advanced Teachers' College with which the Faculty was merged, as noted earlier, had bequeathed a National Certificate in Education (NCE) Programme to the College of Education which originated from the merger, the college offered various education programmes at NCE, Bachelor's and Postgraduate levels. 
The Faculty operated in this shape for almost ten years until the dissolution of the college in 1975 and its replacement by a full-fledge Faculty of Education and an Institute of Education. "The Faculty of Education was charged with long-term professional training of teachers and other education specialists;" "...and cooperates with other faculties in the university, which would teach the content..." before the NCE programmes were gradually phased out and the last set of students completed their programmes in 1982" (p. 2).

The faculty aims at producing competent teachers in keeping with Nigeria commitment to the offering of functional education for productivity. Accordingly "the Faculty's vision and mission are to produce highly motivated, conscientious, efficient, and effective classroom teachers for all levels of Nigeria's educational system" (p. 2) with specific objectives covering such broad areas as teaching, research, and services to the community and the nation.

The philosophy of the Islamic Religious Studies Education programme in the Faculty is grounded on "the need to prepare teachers of Islamic studies who will be able to assist students to play efficiently their spiritual moral social and intellectual role in society (Students' Handbook, 2010 - 2012 p. 30). The specific objectives of the programme are to:

i. Equip prospective Islamic studies teachers, with the requisite knowledge, skills, attitude, and behaviours to discharge their responsibilities in the classroom, school, and societies.

ii Guide students into deeper levels of understanding its culture

iii. Provide a strong platform on which an enduring and peaceful society can be built, using the primary sources of Islam (Qur'an and Hadith).

iv. Provide theoretical and methodological tools for research in Islamic studies Education.

$\checkmark$ Prepare professional teachers competent to impart religious ideas to others.

The curriculum structure of the Lagos Model is presented in Table 2.1 below.

Table 2.1 showing the curriculum structure of the Lagos Model (2017-2019)

\begin{tabular}{|c|c|c|c|c|c|c|c|c|c|c|c|c|}
\hline Year 1 & Semester 1 & $\mathrm{CH}$ & $\begin{array}{c}\text { Year } \\
2\end{array}$ & Semester 1 & $\mathrm{CH}$ & $\begin{array}{c}\text { Year } \\
3\end{array}$ & Semester 1 & $\mathrm{CH}$ & $\begin{array}{c}\text { Year } \\
4\end{array}$ & Semester 1 & & $\mathrm{CH}$ \\
\hline $\begin{array}{l}\text { GST } \\
102\end{array}$ & $\begin{array}{l}\text { Philosophy, Logic } \\
\text { and Philosophy of } \\
\text { Science }\end{array}$ & 2 & $\begin{array}{l}\text { GST } \\
201 \\
\text { FED }\end{array}$ & $\begin{array}{l}\text { General African Studies } \\
\text { Foundations of Education }\end{array}$ & 2 & $\begin{array}{l}\text { FED } \\
311\end{array}$ & $\begin{array}{l}\text { Basic Principles of } \\
\text { Curriculum Development } \\
\text { and Instruction }\end{array}$ & 2 & $\begin{array}{l}\text { FED } \\
413\end{array}$ & $\begin{array}{l}\text { Introduction to } \\
\text { Educational } \\
\text { Management }\end{array}$ & 2 & 2 \\
\hline $\begin{array}{l}\text { GST } \\
105\end{array}$ & Use of English & 2 & 212 & & & $\begin{array}{l}\text { FED } \\
313\end{array}$ & $\begin{array}{l}\text { Measurement and } \\
\text { Evaluation }\end{array}$ & 2 & $\begin{array}{l}\text { FED } \\
414\end{array}$ & Teaching Practice & 2 & 6 \\
\hline FSC & Introduction to & 2 & $\begin{array}{l}\text { FED } \\
213\end{array}$ & $\begin{array}{l}\text { Introduction to Educational } \\
\text { Psychology }\end{array}$ & 2 & & & & ISS & Fiqh III: Islamic and & 2 & 2 \\
\hline $\begin{array}{l}103 \\
\text { CRS }\end{array}$ & $\begin{array}{l}\text { Computer Science } \\
\text { Introduction To the }\end{array}$ & 2 & ASE & Islamic Education: Purpose & 2 & $\begin{array}{l}\text { FED } \\
314\end{array}$ & $\begin{array}{l}\text { Introduction to } \\
\text { Education Technology and } \\
\text { ICT }\end{array}$ & 2 & 411 & $\begin{array}{l}\text { Anti-Crime } \\
\text { Formula }\end{array}$ & & \\
\hline 133 & Study of Religion & & 237 & & & GST & & 2 & $\begin{array}{l}\text { ISS } \\
413\end{array}$ & $\begin{array}{l}\text { Isamic Economic } \\
\text { System }\end{array}$ & 2 & 2 \\
\hline ISS 111 & $\begin{array}{l}\text { Introduction to } \\
\text { Islam }\end{array}$ & 2 & $\begin{array}{l}\text { ISS } \\
231\end{array}$ & $\begin{array}{l}\text { Islamic Hisory II: From } 622- \\
661 \text { CE }\end{array}$ & 2 & $\begin{array}{l}307 \\
\text { ASE }\end{array}$ & $\begin{array}{l}\text { Corporate Governance } \\
\text { Teaching Text }\end{array}$ & 2 & $\begin{array}{l}\text { ISS } \\
418\end{array}$ & $\begin{array}{l}\text { Growth of Islam in } \\
\text { West Africa }\end{array}$ & 2 & 2 \\
\hline ISS 112 & $\begin{array}{l}\text { Introduction to } \\
\text { Qur'an }\end{array}$ & 2 & $\begin{array}{l}\text { ISS } \\
212\end{array}$ & Tajwid and Hifz & 2 & 317 & $\begin{array}{l}\text { Comprehension in Islamic } \\
\text { Studies }\end{array}$ & & ISS & Hadith Literature & 2 & 2 \\
\hline & & & $\begin{array}{l}\text { ISS } \\
213\end{array}$ & The Science of Hadith & 2 & $\begin{array}{l}\text { ISS } \\
311\end{array}$ & $\begin{array}{l}\text { Caliphate in the Medieval } \\
\text { Period }\end{array}$ & 2 & RES & Inter-Religious & 2 & 2 \\
\hline
\end{tabular}

Dinamika Ilmu, Volume 21(2), 2021 
Saheed Ahmad Rufai

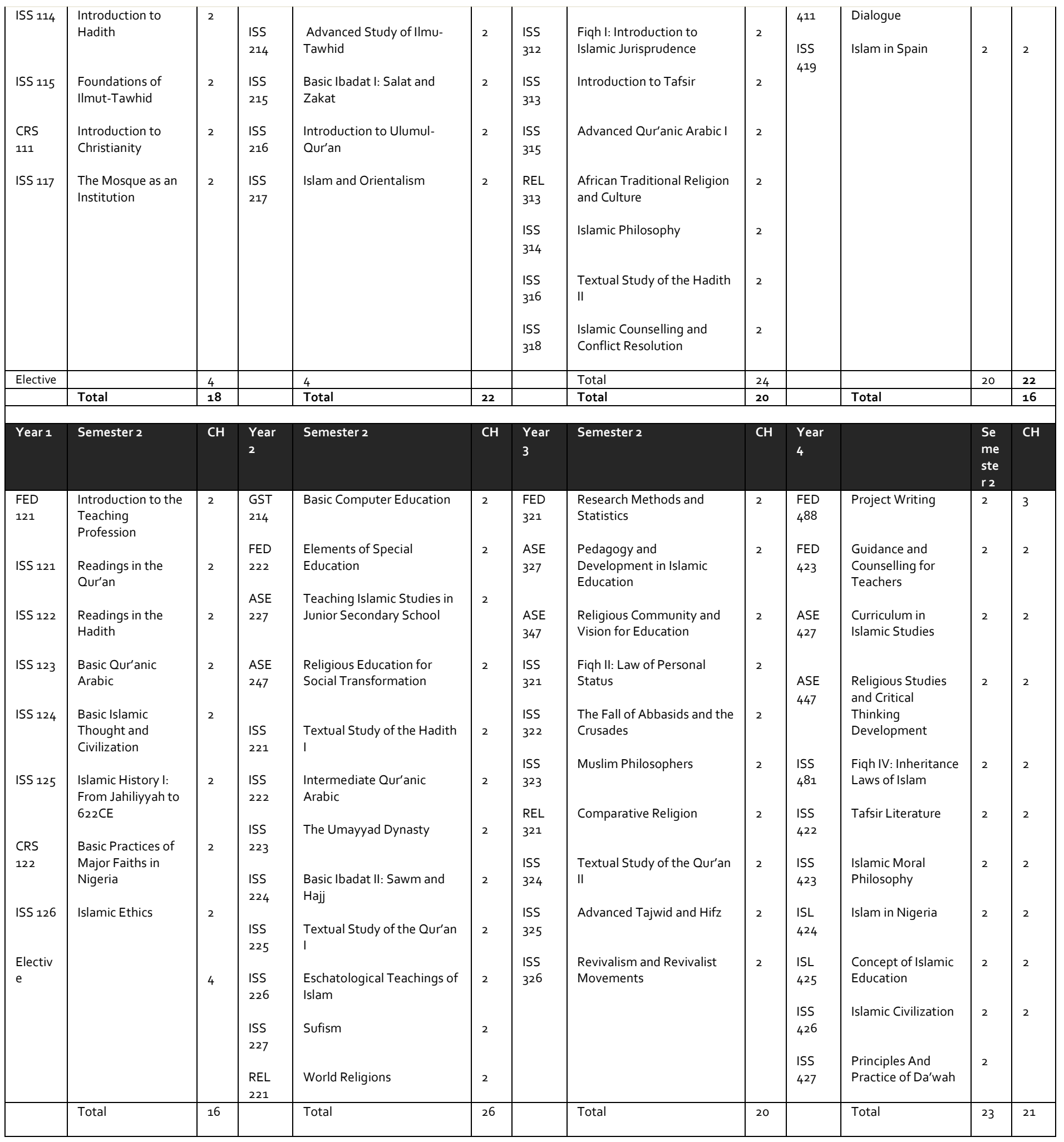




\section{F. Comparative Evaluation of the Programmes}

This section seeks to engage both critically and analytically with the strengths and weaknesses in each of the two-degree programmes, in a comparative fashion. The section also seeks to expose and underscore the commonalities and differences in the two programmes. The commonalities and differences to be highlighted comprise aims, curriculum structure, curriculum content, pedagogy, and evaluation methods, of the programmes..

\section{Aims}

A major commonality in the two programmes is that each of them claims to be aiming at producing teachers who will function as spiritual guides, character builders, and da'wah workers, alongside his role as a transmitter of knowledge. However, it is noticeable that the IIUM model is more committed in this regard than Lagos. For instance, the curriculum of IIUM in this regard is loaded with courses that are capable of aiding the realization of such an objective whereas Lagos runs its Islamic Education Programme in a fashion that is characteristic of a secular system. However, one of the dissimilarities is that while the IIUM model is learner and product-centered, the Lagos programme is processor contentcentered. The implication of this is that the IIUM model may be criticized for paying excessive attention to the learner while the Lagos programme too may be criticized for its failure to pay adequate attention to the learners' needs owing to its concentration on process or methods. Furthermore, the IIUM objectives of Islamic Education programmes are somewhat all-encompassing and all-embracing, while the Lagos Islamic Education Programme objectives are scanty and bereft of depth and necessary Islamic ingredients. It is however interesting to note that the philosophies of the two programmes signify that they are both aimed at producing professional teachers and other educational professionals with the knowledge, skills, and disposition required of an Islamic teacher or education professional. A major deficiency that constitutes a common denominator to the two programmes is the obvious absence from their admission requirements of any instrument that is capable of exposing any undesirable background of prospective teachers. It should be pointed out that this is a major lacuna in the two programmes under review.

\section{Curriculum Structure}

The IIUM programme devotes $13.60 \%$ of its entire credit hours to general education, $36.32 \%$ to professional education, and $50.08 \%$ to specialized education, covering both major and minor areas while Lagos devotes about $4.57 \%$ of the entire programme to general education, $30.92 \%$ to professional education and $54.93 \%$ to specialized education. The implication of this is that both IIUM and Lagos programmes each devote a greater percentage of their credit hours to specialized education at $50.08 \%$ and $54.93 \%$ respectively.

It is a common denominator to the two programmes that the general education component gets the lowest percentage with $13.60 \%$ in IIUM, and $4.57 \%$ in Lagos. What 
this implies is that both programmes attach importance to general education, albeit to varying degrees and with varied ingredients. It is interesting to note that Lagos devotes $30.92 \%$ to the professional education component and IIUM, 36.32\%. The implication of this is that IIUM pays little attention to the professional education component whereas it devotes a greater proportion of its components to the prospective teacher's subject area than does Lagos. It is noteworthy that both IIUM and Lagos devote the heart to general education and the greatest attention to specialized education at 50.08\% and 54.93\% respectively. This shows that there are variations in the structuring, proportioning, sequencing, and distributing of courses in the two programmes.

\section{Curriculum Content}

Curriculum content is of primary importance in view of its centrality to the learning experiences involved in each of the two models. It is therefore of great value to engage with this component with a view to exposing the commonalities and differences in the two models. It is remarkable that religious courses dominate the general education component of IIUM whereas they constitute a notable deficiency in the general education component of the Lagos programme. The implication of this is that the component is one of the strengths of the IIUM model which seems faithful to the idealist orientation of teacher preparation in this regard and a major deficiency or curricular inadequacy of the Lagos model.

However, the two programmes are similar in their professional education components which contain such foundation courses as Sociology of Education, Philosophy of Education, Comparative Education, Educational Measurement and Evaluation, Educational Guidance and counseling as well as pedagogical courses such as Principles of Teaching and Teaching Methods for content. In a similar token, the two programmes also contain courses in Principles of Curriculum Development and Educational Research Methodology. Notwithstanding the noticeable commonalities in this regard, it is noteworthy that major dissimilarities lie in this respect given that the IIUM components of professional education contain contributions from Muslim philosophers, sociologists, psychologists, historians, teachers, and others which are unmistakably missing in the Lagos programme whose professional component seems light in Islamic religious contents.

Table 3.1: A Comparison of the Lagos and IIUM Models of Islamic Education.

\begin{tabular}{|c|c|c|}
\hline $\begin{array}{l}\text { Curriculum } \\
\text { Components }\end{array}$ & IIUM & LAGOS \\
\hline Aims & $\begin{array}{l}\text { Sources of objectives are the Qur'an, } \\
\text { Sunnah, Maqasid al-Shari'ah, society } \\
\text { and contemporary scholarship }\end{array}$ & $\begin{array}{l}\text { Sources of objectives are the learners, } \\
\text { the contemporary life after school, } \\
\text { and the subject matter. }\end{array}$ \\
\hline & $\begin{array}{l}\text { Philosophy is learner-product } \\
\text { centered. }\end{array}$ & Philosophy is process - centred \\
\hline Admission criteria & $\begin{array}{l}\text { Purely academic and professional in } \\
\text { nature }\end{array}$ & $\begin{array}{l}\text { Purely academic and professional in } \\
\text { nature }\end{array}$ \\
\hline
\end{tabular}




\begin{tabular}{|c|c|c|}
\hline Orientation & $\begin{array}{l}\text { Pays attention to spiritual } \\
\text { development as well as the } \\
\text { development of other domains of } \\
\text { learning by assessing knowledge, skills } \\
\text { and values. }\end{array}$ & $\begin{array}{l}\text { Focuses on cognitive, development of } \\
\text { the recipient of knowledge. }\end{array}$ \\
\hline \multicolumn{3}{|l|}{ Curriculum structure: } \\
\hline General education & $13.60 \%$ & $4.15 \%$ \\
\hline Professional education & $36.32 \%$ & $30.52 \%$ \\
\hline \multirow{2}{*}{$\begin{array}{l}\text { Specialized education } \\
\text { (Major and Minor) }\end{array}$} & $50.08 \%$ & $64.93 \%$ \\
\hline & $\begin{array}{l}\text { Specialized education receives greater } \\
\text { attention }(50.08 \%) \text {. Halaqah and } \\
\text { ta'aruf system are included as part of } \\
\text { co-curricular activities }\end{array}$ & $\begin{array}{l}\text { Specialized education receives greater } \\
\text { attention }(64.93 \%)\end{array}$ \\
\hline Curricular content & $\begin{array}{l}\text { University core component }(13.60 \%) \\
\text { contains religious education courses }\end{array}$ & $\begin{array}{l}\text { General education (or University core } \\
\text { course) component contains little or } \\
\text { no evidence of religious orientation. }\end{array}$ \\
\hline Professional education & $\begin{array}{l}\text { Professional courses }(16.32 \%) \text { are } \\
\text { taught from Islamic perspective }\end{array}$ & $\begin{array}{l}\text { Professional education }(40.52 \%) \text { is } \\
\text { aimed at making the teacher ground } \\
\text { in method, curriculum and foundation }\end{array}$ \\
\hline Specialized education & $\begin{array}{l}\text { Specialized education (50.08\%) is } \\
\text { aimed at making the teacher have a } \\
\text { good command of a subject area, with } \\
\text { Islamic ingredients. }\end{array}$ & $\begin{array}{l}\text { Specialized education } 64.93 \% \text { is } \\
\text { aimed at making the teacher have a } \\
\text { subject area or specialization. }\end{array}$ \\
\hline Pedagogy & $\begin{array}{l}\text { Pedagogy depends on institutional } \\
\text { facility and the teacher's creativity and } \\
\text { Islamic approach }\end{array}$ & $\begin{array}{l}\text { Pedagogy depends on the teacher's } \\
\text { creativity and available facilities. }\end{array}$ \\
\hline Evaluation method & $\begin{array}{l}\text { Evaluation is aimed at determining the } \\
\text { degree of the realization of an } \\
\text { integrated personality }\end{array}$ & $\begin{array}{l}\text { Evaluation is aimed at determining } \\
\text { the realization of educational aims } \\
\text { and objectives vis-à-vis contemporary } \\
\text { needs. }\end{array}$ \\
\hline
\end{tabular}

\section{G. Discussion}

This section of the study demonstrates how the findings from this paper compare with findings from other relevant studies. The scholarship of curriculum and pedagogy in Islamic settings is replete with studies on curriculum planning, development, integration, and evaluation (Fraser, 2000; Etim, 2005; Lake, 2011; Loepp, 2007; Khairiah \& Sirajuddin, 2019; Niyozof \& Memon, 2020). This section assesses the level of consistency or otherwise, of each of the models evaluated, with such principles. It is remarkable that the findings of this paper from the two models suggest consistency with some of the curriculum principles espoused in those studies, though there are instances of deviation from such curriculum construction principles. For instance, the Lagos model devotes a whole semester to the teaching of a number of single-topic courses like ASE 237 (Islamic Education: Purpose and Pedagogy), ISS 425 (Concept of Islamic Education), ASE 427 (Curriculum in Islamic 


\section{Saheed Ahmad Rufai}

Studies). The technical pitfall in the nomenclature of ASE 237 is that Islamic education is a system and a process, not a content like Islamic Studies that could be situated in Pedagogy as its vehicle. This line of thinking finds support in the fact that another course in the same model, ASE 427 is tagged 'Curriculum in Islamic Studies' not 'Islamic Education'. Making the prospective teacher circumambulate the 'Concept of Islamic Education' for a whole semester in his/her final year and while on the verge of graduation, leaves much to be desired concerning the logic or illogic of the curriculum sequencing captured in the literature (Leopp, 2007; Noyzof \& Memon, 2020).

The IIUM Model also offers some single-topic courses like EDI 1801 (Fiqh-uls-Sirah), which adds little value to the quality of teacher preparation whereas it is taught for a whole semester. Like the IIUM Model, the Lagos Model is guilty of inaccurate course proportioning and content sequencing where it devotes a whole semester to the teaching of a number of single-topic courses like ASE 237 (Islamic Education: Purpose and Pedagogy), ISS 425 (Concept of Islamic Education), ASE 427 (Curriculum in Islamic Studies). The technical pitfall in the nomenclature of ASE 237 is that Islamic education is a system and a process, not a content like Islamic Studies that could be situated in Pedagogy as its vehicle. This line of thinking finds support in the fact that another course in the same model, ASE 427 is accurately tagged 'Curriculum in Islamic Studies' not 'Islamic Education'. Making the prospective teacher to circumambulate the 'Concept of Islamic Education' for a whole semester in his/her final year and while on the verge of graduation, leaves much to be desired concerning the logic and illogic of the curriculum ordering and proportioning.

Closely related to the focus of professional education is the provision made by the IIUM Model for the monitoring of the development of integrated personality and Islamic teacher and worker in the prospective teacher, whereas such a provision is totally lacking in the Lagos Model. It must be acknowledged that both models are largely consistent with the principles of curriculum structuring (Jensen, 1998; Mansfield, 2019). For instance, it is obvious that the proportioning of the professional components in the two models are faithful to pedagogical scholarship which emphasizes the need for the professional deployment of creativity by the curricularist in a bid to fashion out a new educational blueprint from a set of learning materials and favours an innovative method of organizing learning for a systematic delivery (Drake, 2018; Drake \& Burns, 2014; Loepp, 2019; Dressel, 1958; Eccel, 1984; Etim, 2005; Fraser, 2000) It is therefore remarkable that the models are not inconsistent with the professional path of curricularists in their method of organizing content as interwoven, connected, thematic, interdisciplinary, multidisciplinary, correlated, linked, or holistic curriculum.

\section{H. Conclusion}

This study has engaged comparatively with two different Islamic Education degree programmes with a view to evaluating their strengths and deficiencies, for possible improvement or enrichment. The study found that each of the two models has its own peculiarities as well as comparative strengths and weaknesses. It also found that while IIUM is committed to the production of an integrated and holistic personality in the 
teacher, the Lagos model is committed to the training of a Muslim transmitter of knowledge and moral values. The comparative evaluation also revealed that IIUM, though not without its deficiencies, offers a better modern Islamic alternative to the dominant Western Models of teacher education, whereas the Lagos programme seems to have no clear-cut direction in this regard. One of the most remarkable differences in the programmes as revealed by the comparative evaluation is the fact that in the IIUM pedagogy, the prospective teacher is trained to be able to use the latest technology in teaching his subject whereas the Lagos pedagogy seems "struggling" to catch up, in this regard. Nonetheless, neither of the two models is able to detach itself totally from the influence of the dominant Western models especially with regard to pedagogy which is why they can be regarded, though to varied degrees, as partial adoption of such dominant Western Islamic education degree programme, as being offered in non-Muslim settings. This is evident in several instances of partial duplication, unacknowledged replication, and veiled contextualization of some of the dominant western models, which characterize the two models, albeit to varied degrees. The paper offered propositions for possible reforms on the two models.

\section{BIBLIOGRAPHY}

Abaza, M. (2018). Asia Imagined by the Arabs. In K. Bustamam-Ahmad \& Patrick Jory (Eds.), Islamic Studies and Islamic Education in Contemporary Southeast Asia. (pp.7592). Yayasan Ilmuwan.

Abu Bakar, C. (2018). Mainstreaming Madrasah Education in the Philippines: Issues, Problems, and Challenges. In K. Bustamam-Ahmad \& Patrick Jory (Eds.), .Islamic Studies and Islamic Education in Contemporary Southeast Asia. (pp.75-92). Yayasan Ilmuwan.

Amanullah, M. (2004). Evaluation of the Undergraduate Curriculum of the Department of Fiqh and Usul-Al-Fiqh of the International Islamic University Malaysia. Muslim Education Quarterly. 21(3), 2016.

Ashraf, A. \& Hussein, S. (1979). Crisis in Muslim Education. Hodder and Stoughton King Abdul-Aziz University.

Arjmand, R. (2018). Islamic Education, Historical Perspective, Origin, and Foundation. In Holger Daun and Reza Arjmand (ed.), Handbook of Islamic Education. (pp. 3-31). Springer.

Azra, A. (2018). From IAIN to UIN: Islamic Studies in Indonesia. In K. Bustamam-Ahmad \& Patrick Jory (Eds.), Islamic Studies and Islamic Education in Contemporary Southeast Asia. (pp.43-56). Yayasan Ilmuwan.

Baiza, Y. (2018). Islamic Education and Development of Educational Traditions and Institutions. In Holger Daun \& Reza Arjmand (Eds.), Handbook of Islamic Education. (pp. 77-97). Springer. 
Saheed Ahmad Rufai

Bajunid, F.O. (2018). Islamic Education in Mainland Southeast Asia: The Dilemmas of Muslim Minorities. In K. Bustamam-Ahmad \& Patrick Jory (Eds.), Islamic Studies and Islamic Education in Contemporary Southeast Asia. (pp. 159-178). Yayasan Ilmuwan. Baloch, N.A. \& Al-Fendi, M.A.(1980). Curriculum and Teacher Education. Hodder and Stonghton and King Abdul-Azeez University.

Bustamam-Ahmad, K. \& Jory, P. (2018). Introduction. In Kamaruzzaman BustamamAhmad \& Patrick Jory (Eds.), Islamic Studies and Islamic Education in Contemporary Southeast Asia. (pp. v-xix). Yayasan Ilmuwan.

Dressel, P. (1958). "The Meaning and Significance of Integration" In Henry Nelson (ed.) The Integration of Educational Experience, $57^{\text {th }}$ Yearbook of the National Society for the Study of Education. University of Chicago Press.

Drake, S. M., \& Burns, R. C. (2014). Meeting standards through integrated curriculum. Association for Supervision and Curriculum Development.

Eccel, A.C. (1984). Egypt, Islam and Social Change: Al-Azhar in Conflict and Accommodation. Klaus Schwaz Verlag.

Etim, J. S. (2005). Curriculum integration K-12: Theory and practice. University Press of America.

Fraser, D. (2000). Curriculum integration: What it is and is not set: Research Information for Teachers. 3, 34-37.

Gillet, May. (1989). The IAIN Indonesian Higher Education. Proceedings of the VII World Congress of Comparative Education June, 1989. pp. 255-172, Montreal, Canada.

Hasan, N., P. (2018). Salafi Madrasahs and Islamic Radicalism in Post New Order Indonesia. In K. Bustamam-Ahmad and Patrick Jory (Eds.), Islamic Studies and Islamic Education in Contemporary Southeast Asia. (pp.93-112). Yayasan Ilmuwan

Ibn Sina (1974). The Book of Teaching. Routledge.

ISESCO (1990). On Strategy for the development of education in the Islamic countries. ISESCO Publications.

Jacobs, H.H. (ed.) (1989). Interdisciplinary Curriculum: Design and Implementation. Association for Supervision and Curriculum Development.

Jensen, E. (1998). Teaching with the brain in mind. Association for Supervision Curriculum Development.

Khairiah, K. \& Sirajuddin, S. (2019). The Effect of University Leadership Management: Efforts to Improve the Education Quality of State Institute for Islamic Studies (IAIN) of Bengkulu. Jurnal Pendidkan Islam, 7(2)

Kosterec, M. (2015). Analytic Method. Organon. 23(1)

Lake, K. (2011). Integrated Curriculum. School Improvement Research Series. Sage Publication.

Loepp, F. L. (2007). Models of Curriculum Integration. Journal of Technology Studies, 22(5).

Loepp, I. P. (2007). Primary Programs Framework - Curriculum Integration: Making Connections. Alberta Education. 
Makdisi, G., (1981). The Rise of Colleges: Institutions of Learning in Islam and the West Edinburgh University Press.

Mansfield, B. (1989). Students' Perception of an Integrated Unit: A Case Study: Social Studies 80(4), 135-140.

Manuty, M.N. (2018) Islamic Studies Programs in Malaysia's Higher Learning Institutions: Responses to Contemporary Challenges of Modernity, Globalization and Post-9/11. In Kamaruzzaman Bustamam-Ahmad and Patrick Jory (Eds.), Islamic Studies and Islamic Education in Contemporary Southeast Asia. (pp. 137-158). Yayasan Ilmuwan

Muhammad, K. (2018). Foreword. In Kamaruzzaman Bustamam-Ahmad \& Patrick Roy

(Eds.), Islamic Studies and Islamic Education in Contemporary Southeast Asia. (pp.iii-iv). Yayasan Ilmuwan

Mardman, H (2018). Egypt's Influence on the Education of Thai Muslims from the Nasser Era to the Present. In Kamaruzzaman Bustamam-Ahmad \& Patrick Jory (Eds.). .Islamic Studies and Islamic Education in Contemporary Southeast Asia. (pp. 29-55). Yayasan Ilmuwan

Munadi, M., Emawati, F. \& Hakiman, A, (2019). The Reality of Knowledge Management in Islamic Higher Education, Jurnal Pendidkan Islam, 7(2).

Nakosteen,M. (1978). History of Islamic Origins of Western Education AD 800-1350. Shambalaha Publication.

Niyozof, S. \& Memon, N. (2020). Editorial to Special Issue; Contemporary Critical Perspectives in Islamic Education, Religions 11, 672.

Rosnani, H. (1996). Islamization and the Role of the Department of Education, International Islamic University. Seminar on the Islamization of Knowledge. International Islamic University Malaysia.

Rosnani, H. (1997). The Reconstruction of an Islamic-Based Teacher Education Programme. In Ahmad Ashraf (ed.) Muslim Education Quarterly 14(2)

Rosnani, H. (2007). Intellectualism in Higher Islamic Traditional Studies: Implications for the Curriculum. American Journal of Islamic and Social Sciences. 24 (3)

Ross, D.D. (1984) An Introduction to Curriculum Criticism. Journal of Thought 19(2), 1984.

Saeed, A. (2018). Shariah and Education: A Brief Overview. In Holger Daun \& Reza Arjmand (Eds.), Handbook of Islamic Education. (pp. 33-42). Springer.

Shamsul, A.B. \& Aziz, A. (2018). Egypt's Influence on the Education of Thai Muslims from the Nasser Era to the Present. In K. Bustamam-Ahmad \& Patrick Jory (Eds.). Islamic Studies and Islamic Education in Contemporary Southeast Asia (pp. 113-136). YayasanIlmuwan.

Stanton, C.M., (1990). Higher Learning in Islam: The Classical Period AD 700-1300. Rowman and Littlefield Publishers Inc.

Tritton, A.S. (1957). Materials on Muslim Education in the Middle Ages. Lucas.

Zakaria, R. (2007). Overview of Indonesian Islamic Education: A Social, Historical a Political Perspective. Unpublished Thesis. University of Waikito.

Zakariyah, B. (2008). A Historical Study of Islamic System of Education [University of Mutta]

Dinamika Ilmu, Volume 21(2), 2021 
Saheed Ahmad Rufai

Zaman, M. (2018). Islamic Education: Philosophy. In H. Daun \& Reza Arjmand (Eds.), Handbook of Islamic Education. (pp. 61-75). Springer. 